The University of Maine

\title{
DigitalCommons@UMaine
}

Marine Sciences Faculty Scholarship

School of Marine Sciences

$12-1-2005$

\section{Reproductive Biology of the Deep-Sea Polychaete Gorgoniapolynoe Caeciliae (Polynoidae), a Commensal Species Associated with Octocorals}

Kevin Eckelbarger

University of Maine - Main, kevine@maine.edu

Les Watling

University of Maine - Main, watling@maine.edu

H. Fournier

Follow this and additional works at: https://digitalcommons.library.umaine.edu/sms_facpub

\section{Repository Citation}

Eckelbarger, Kevin; Watling, Les; and Fournier, H., "Reproductive Biology of the Deep-Sea Polychaete Gorgoniapolynoe Caeciliae (Polynoidae), a Commensal Species Associated with Octocorals" (2005). Marine Sciences Faculty Scholarship. 106.

https://digitalcommons.library.umaine.edu/sms_facpub/106 


\title{
Reproductive biology of the deep-sea polychaete Gorgoniapolynoe caeciliae (Polynoidae), a commensal species associated with octocorals
}

\author{
K.J. Eckelbarger* ${ }^{\ddagger}$, L. Watling* and Heidi Fournier ${ }^{\dagger}$ \\ *Darling Maine Center, The University of Maine, 193 Clark's Cove Road, Walpole, Maine 04573, USA. 'Department of Biology, \\ Roger Williams College, One Old Ferry Road, Bristol, RI 02809, USA. \\ ${ }^{\ddagger}$ Corresponding author, e-mail: kevine@maine.edu
}

\begin{abstract}
Some aspects of the reproductive biology of the polychaete Gorgoniapolynoe caeciliae have been described for the first time. Gorgoniapolynoe caeciliae is a deep-sea commensal species associated with Candidella imbricata, an octocoral that populates the New England Seamount chain. Gorgoniapolynoe caeciliae is a dioecious species with an equal sex ratio and fertile segments throughout most of the adult body. The gonads of both sexes are associated with genital blood vessels emerging from the posterior surface of most intersegmental septa. In the female, oogenesis is intraovarian with oocytes being retained within the ovary until vitellogenesis is completed. The largest female examined contained over 3000 eggs with a maximum diameter of $80-90 \mu \mathrm{m}$. In the male, the testes are repeated in numerous segments and consist of small clusters of spermatogonia, spermatocytes, and early spermatids associated with the walls of the genital blood vessels. Early spermatids are shed into the coelom where they complete differentiation into mature ect-aquasperm with a spherical head $(4 \mu \mathrm{m})$, a small cap-like acrosome, and a short mid-piece with four mitochondria. Indirect evidence suggests that this species is an annual breeder that releases its gametes into seawater and produces a planktotrophic larva following fertilization. The reproductive biology of $G$. caeciliae is consistent with that of most other polynoids including many shallow water species suggesting that phylogenetic history strongly shapes its biology.
\end{abstract}

\section{INTRODUCTION}

Polychaetous annelids are notable among invertebrates for their rich diversity of life history features (Wilson, 1991; Giangrande, 1997; Pernet et al., 2002). However, only about $3 \%$ of extant species have had their life histories described in detail and most of these inhabit shallow water (Giangrande, 1997). Our knowledge of the reproductive biology of deep-sea polychaetes is mostly confined to a few species from hydrothermal vent and methane seep habitats. They include members of the Alvinellidae, the Amphretidae, the Polynoidae, the Hesionidae, and the Orbiniidae (reviewed in Eckelbarger \& Young, 2002; Young, 2003). Limited information is also available for a few species not associated with either vents or seep sites (Blake, 1993; Blake \& Watling, 1994).

The Polynoidae ('scaleworms') represents the second largest polychaete family and is a highly diverse group presently composed of 20 subfamilies. Polynoids are commonly encountered in deep-sea habitats (Pettibone, 1984), particularly abyssal plains and deep-sea trenches (Levenstein, 1984) but also at high-temperature hydrothermal chimneys, diffuse venting areas, and on decomposing organic matter including whale carcasses (Chevaldonné et al., 1998; Jollivet et al., 2000). At least 40 species have been described to date at hydrothermal vents alone (Tunnicliff et al., 1998). Many polychaetes form commensal relationships with other invertebrate groups and about $55 \%$ of the known commensal species belong to the Polynoidae (reviewed by Martin \& Britayev, 1998). While most polynoids are free-living, nearly $23 \%$ maintain commensal lifestyles. Approximately 20\% of the host species are cnidarians (Martin \& Briteyev, 1998), including deep-sea gorgonians (Pettibone, 1991). Some polynoids have evolved unique morphological adaptations as a result of their commensal life (Pettibone, 1984) but it is difficult to assess whether or not reproductive divergences have occurred because so little is known about their life histories (Martin \& Britayev, 1998; Jollivet et al., 2000).

Connections between reproductive biology, habitat, and lifestyle lie at the heart of evolutionary and ecological theory. The role of these connections in deep-sea species have received widespread attention (Tyler \& Young, 1999; Young, 2003) but almost all of it has been confined to vent and cold seep habitats. Far less is known about the life histories of non-vent and non-seep species. Deep-sea species offer unique opportunities for exploring reproductive evolution because they are subjected to significantly different selective pressures than their shallow water relatives that could result in novel life history divergence. The critical role of phylogenetic history in moulding life history patterns has been examined in both shallow water and deep-sea invertebrates (e.g. Eckelbarger \& Watling, 1995). Recent investigations of the reproductive biology of deepsea invertebrates indicate that phylogenetic constraints impose boundaries on many species (Eckelbarger \& Watling, 1995; Young \& Tyler, 1997; Hodgson et al., 1998; 

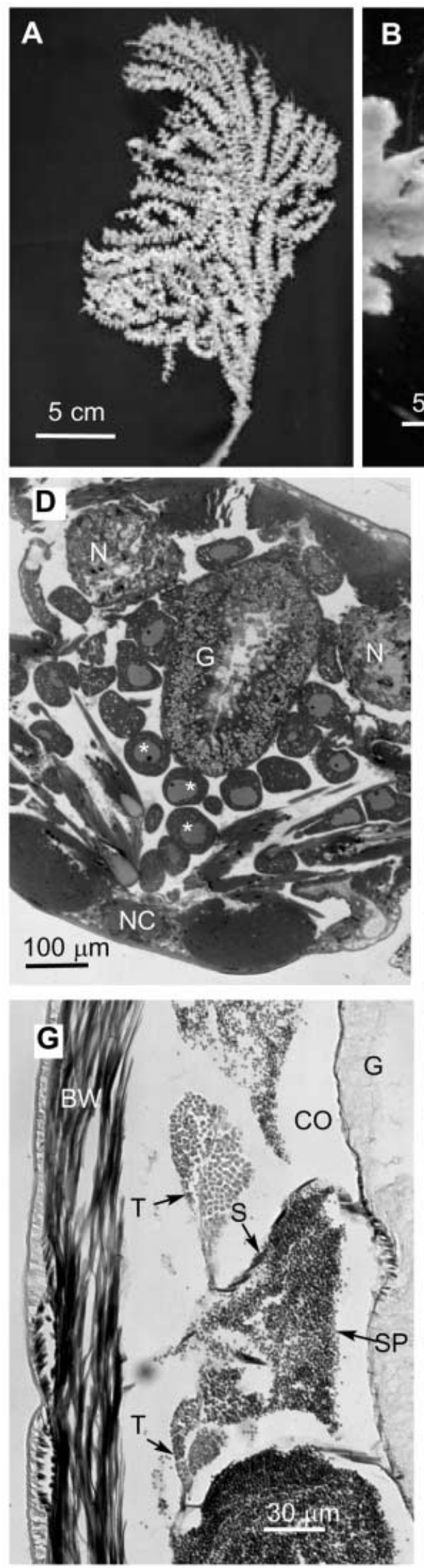
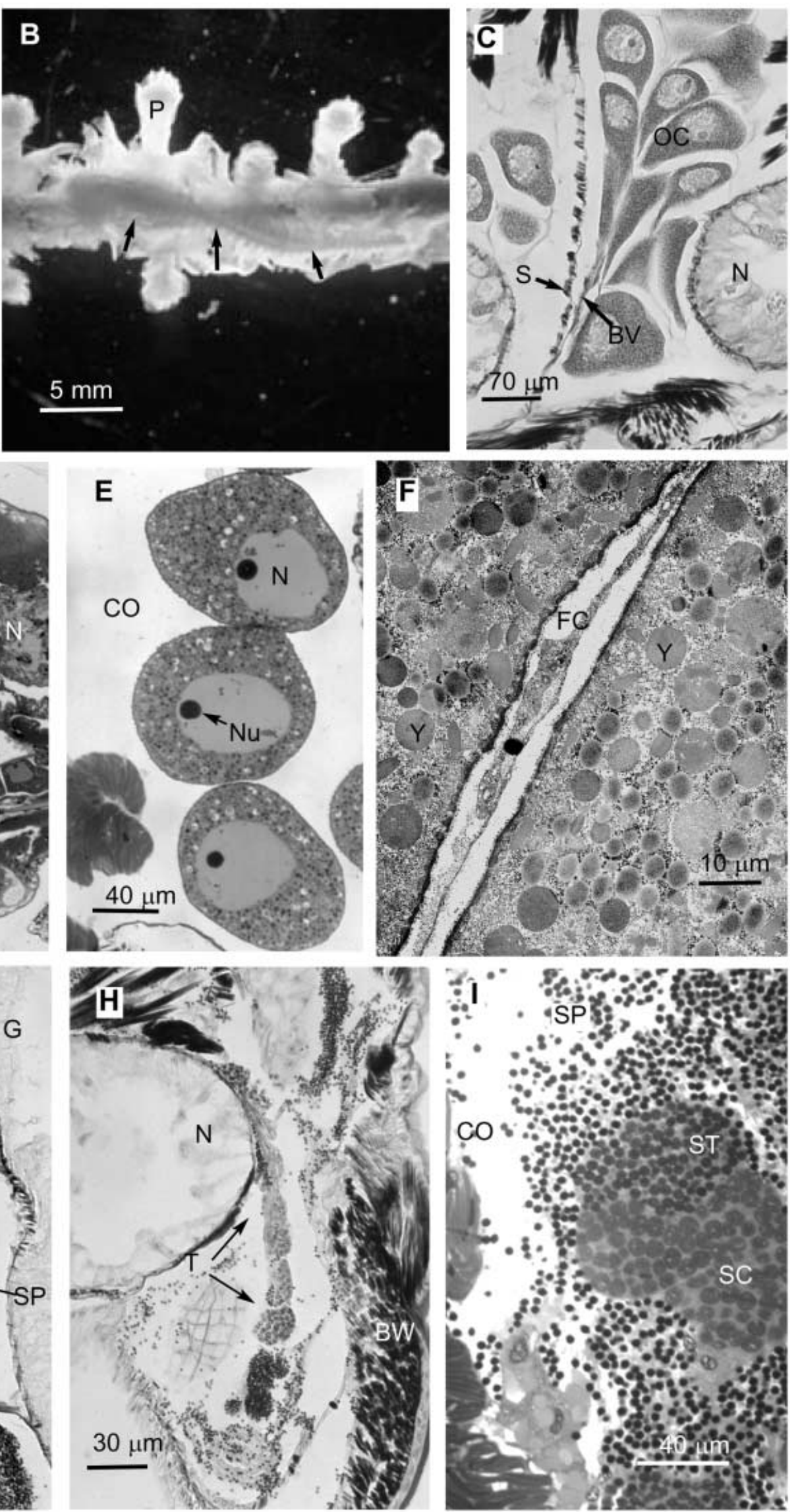
Eckelbarger \& Young, 1999, 2002; Eckelbarger et al., 2001; Young, 2003).

Gorgoniapolynoe caeciliae (Fauvel, 1913) is a deep-sea polynoid (subfamily Polynoinae) associated with Candidella imbricata (Gorgonacea: Primnoidae), an octocoral that populates deep-sea localities in the North Atlantic (Figure 1A). Gorgoniapolynoe caeciliae is distributed in both the eastern and western North Atlantic Ocean and has a previously reported depth range of 152-1543 m (Pettibone, 1991). Through an unknown mechanism, it induces the octocoral to form open-ended tunnels or covered galleries on its branches within which the worms reside (Bayer, 1964) (Figure 1B). Previous studies of polynoid commensals indicated that diffusible chemicals released by various hosts serve as attractants for the worms (Davenport, 1966) and it has been suggested that host recognition by settling polynoid larvae is likely involved (Martin \& Britayev, 1998). However, our knowledge of the reproductive biology of commensal polynoids is very limited. It is of interest to determine what, if any, life history divergences have occurred in this species as a consequence of its commensal life style and/or deep-sea distribution. In this paper, we describe the general features of the reproductive biology of $G$. caeciliae and compare it with the known life histories of other polynoids including those associated with hydrothermal vents.

\section{MATERIALS AND METHODS}

\section{Sample collection}

Living specimens of Gorgoniapolynoe caeciliae were obtained as commensals living on colonies of the octocoral, Candidella imbricata, collected on several seamounts of the New England Seamount Chain. Octocorals with their associated commensals were collected on 15 July 2003 at Kelvin Seamount $\left(38^{\circ} 47^{\prime} \mathrm{N} 64^{\circ} 08^{\prime} \mathrm{W}\right)$ at $2061 \mathrm{~m}$ using the submersible 'Alvin'. Additional specimens were collected with the remotely operated vehicle (ROV) 'Hercules' on 15 May 2004 at Manning Seamount $\left(38^{\circ} 08.09^{\prime} \mathrm{N} 61^{\circ} 06.965^{\prime} \mathrm{W}\right)$ at $1718 \mathrm{~m}$, on 20 May 2004 at Kelvin Seamount $\left(38^{\circ} 51.3805^{\prime} \mathrm{N} \quad 63^{\circ} 46.352^{\prime} \mathrm{W}\right)$ at $1959 \mathrm{~m}$, and at Balanus Seamount $\left(39^{\circ} 21.4977^{\prime} \mathrm{N}\right.$ $65^{\circ} 21.8229^{\prime} \mathrm{W}$ ) on 21 May 2004 at $1766 \mathrm{~m}$. Specimens were brought to the surface ship via an insulated biobox on both the submersible and ROV and immediately transferred to buckets containing chilled $\left(4^{\circ} \mathrm{C}\right)$, unfiltered seawater, and stored in the walk-in cold room on the ship (RV 'Atlantis' in 2003, and RV 'Ronald H. Brown' in 2004).

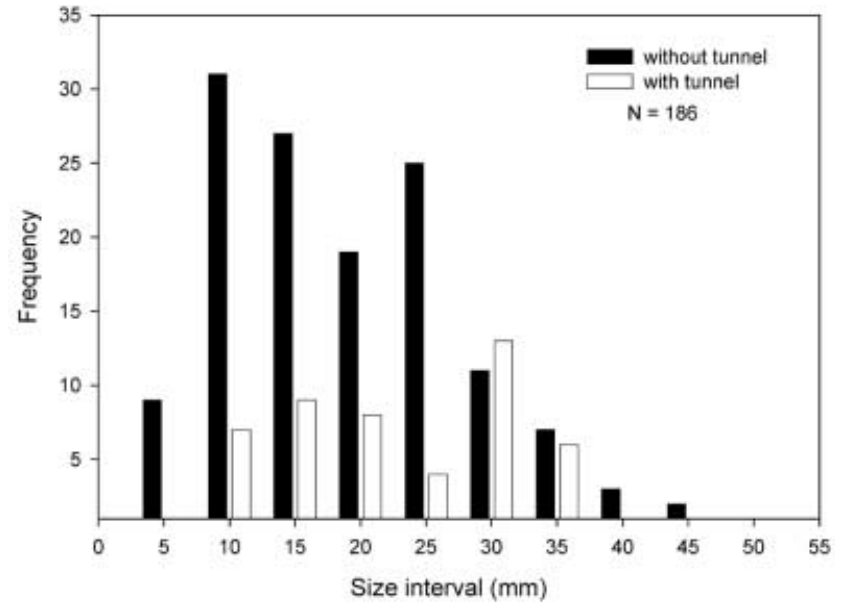

Figure 2. Size-frequency distribution of internode branches of the octocoral Candidella imbricata with and without Gorgoniapolynoe caeciliae tunnels.

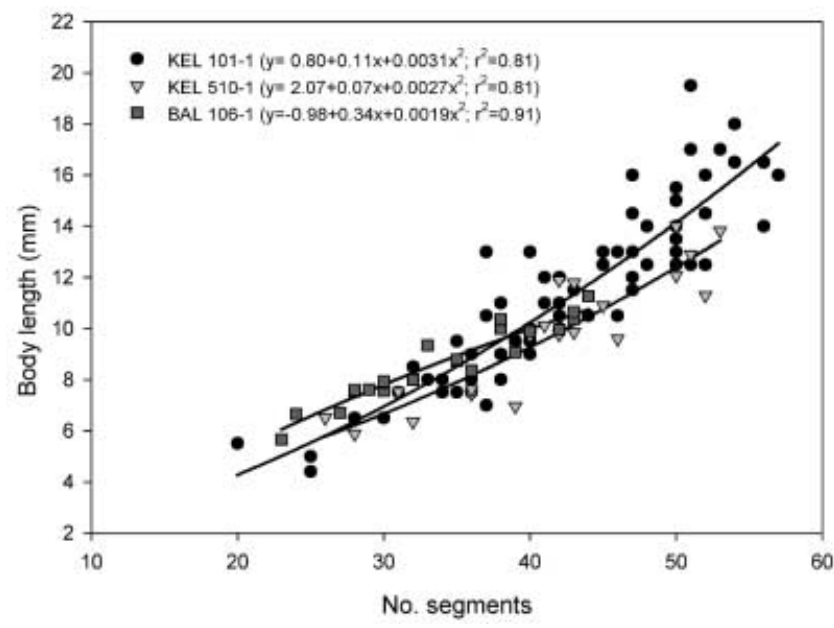

Figure 3. Body length vs segment number for Gorgoniapolynoe caeciliae collected at two sites on Kelvin (KEL) Seamount and one site on Balanus (BAL) Seamount. The KEL 101-1 site was sampled in July 2003, while the KEL 510-1 and BAL 106-1 sites were sampled in May, 2004.

\section{Histology}

Whole specimens of $G$. caeciliae were fixed by immersion in Hollande's fixative for $24 \mathrm{~h}$ and processed using standard paraffin histology. Following embedding in paraffin, $10 \mu \mathrm{m}$ sections were cut with a Microm HM 325 microtome, stained with Gomori's trichrome, and examined

Figure 1. (Opposite) (A) Preserved specimen of the octocoral Candidella imbricata; (B) higher magnification of single branch of C. imbricata showing the polynoid, Gorgoniapolynoe caeciliae, inside its tunnel (arrows) formed from the basal sclerites of adjacent polyps $(\mathrm{P})$; (C) parasagittal paraffin section of female showing oocytes (OC) attached to genital blood vessels (BV) that originate from the posterior surface of an intersegmental septum (S). N, nephridium; (D) transverse semi-thin section through female showing free-floating eggs $\left(^{*}\right)$ in coelom. N, nephridium; G, gut; NC, ventral nerve cord; (E) semi-thin section showing coelomic eggs with prominent nuclei $(\mathrm{N})$ and single nucleolus $(\mathrm{Nu})$; $\mathrm{CO}$, coelom; (F) electron micrograph through the cortical region of adjacent eggs separated by squamous follicle cells $(F C)$. Y, yolk; $(G)$ parasagittal paraffin section through a male showing testes (T) budding from the intersegmental septa (S) of two adjacent segments. CO, coelom; SP, mature sperm; BW, ventral body wall; $\mathrm{G}$, gut; $(\mathrm{H})$ parasagittal paraffin section through male showing testis $(\mathrm{T})$ adjacent to nephridium $(\mathrm{N})$. BW, ventral body wall; (I) semi-thin section of male showing mature sperm (SP) in coelom adjacent to clusters of spermatocytes (SC) and spermatids (ST) that remain attached to genital blood vessels (not shown). 

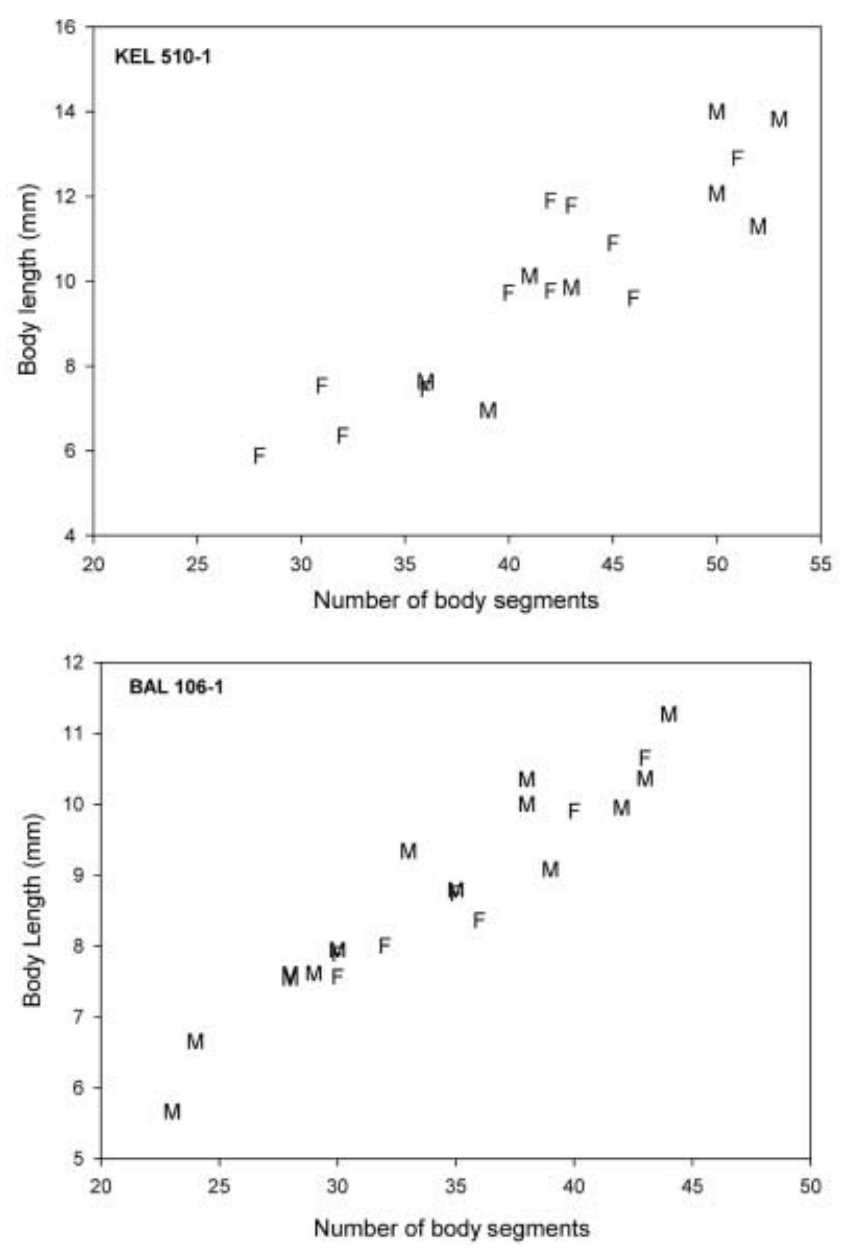

Figure 4. Body length vs segment number of male and female specimens collected at the Kelvin and Balanus Seamounts in May, 2004.

with an Olympus BH-2 photomicroscope. Photographic images were taken using a Retiga Ex Q-Imaging digital camera and an Olympus 35AD-4 camera.

\section{Electron microscopy}

Ultrastructural studies were conducted on six male and seven female adult specimens. Transverse sections of animals were fixed by immersion for $90 \mathrm{~min}$ at room temperature in $2.5 \%$ glutaraldehyde buffered with $0.2 \mathrm{M}$ Millonig's phosphate buffer, rinsed three times for $15 \mathrm{~min}$ each in 0.4 M Millonig's buffer, and post-fixed for $90 \mathrm{~min}$ at room temperature in $1 \%$ osmium tetroxide buffered with $1.25 \%$ sodium bicarbonate. Tissue was then dehydrated in ascending concentrations of ethanol to $100 \%$, followed by two changes with propylene oxide $(5 \mathrm{~min}$ each), and embedded in Epon. Thin sections were cut with a diamond knife on a Porter-Blum MT2-B ultramicrotome, stained with uranyl acetate and lead citrate, and examined in a Zeiss 900 transmission electron microscope.

\section{Number of fertile segments and fecundity}

Gorgoniapolynoe caeciliae is a relatively small species so we were able to count all of the mature eggs in each female.
Parasagittal, paraffin serial sections were examined with a compound microscope and every egg with a visible nucleolus was counted.

\section{RESULTS}

Specimens of Gorgoniapolynoe caeciliae were abundant on the colonies of Candidella imbricata we examined, with as many as 120 specimens being recovered from the branches of about one-fourth of a single colony. All specimens were found living in tunnels formed of modified sclerites, which the worm somehow induces the octocoral to produce. Each modified sclerite occurs at the base of the octocoral polyp, and may be derived from either a basal polyp sclerite or an adjacent sclerite of the coenenchyme. A worm tunnel may consist of as many as five pairs of modified sclerites (Figure 1B).

Candidella imbricata is a highly branched primnoid octocoral (Figure 1A). With the exception of the basal-most part of a main branch, there is either no $G$. caeciliae tunnel, or only one tunnel, between each pair of branch nodes. Internodes smaller than $10 \mathrm{~mm}$ do not contain tunnels, and only a small proportion of internodes between 10 and $25 \mathrm{~mm}$ in size have tunnels (Figure 2). Only $50 \%$ of the $30-40 \mathrm{~mm}$ internodes are occupied by tunnels.

Gorgoniapolynoe caeciliae is a gonochoric species with no indications of sexual dimorphism. From a sample of 40 adults collected at Kelvin Seamount, 22 were female, 17 were male, and one was of indeterminate sex. The computed sex ratio was insignificantly different from unity (chi-squared test) at 1.29:1 (female:male). One hundred and thirteen specimens examined from Kelvin and Balanus Seamounts ranged from 4.4 to $19.5 \mathrm{~mm}$ in length with total segments numbering between 20 and 57 (Figure 3). In 2003, sexes could not be determined as no gonadal products were present and this species has no apparent external sexual characters. However, worms collected from Kelvin and Balanus Seamounts in 2004 were sexually mature and could be examined histologically for the presence of eggs or sperm. For those worms whose sex was determined, there appeared to be no difference in body size or segment number between males and females at either Kelvin or Balanus Seamounts (Figure 4). More females were collected at Kelvin Seamount and more males at Balanus Seamount, but these numbers are based on only three $C$. imbricata colonies and most likely did not reflect a broad pattern.

The distribution of fertile segments differs slightly between the sexes and shows minor inter-sexual variability. In both males and females, fertile segments extend from segment 7 to within four segments of the posterior end in the male and to within seven segments of the posterior end in the female. In histological sections of both sexes, the presence of gametes was first detected in specimens that were $\sim 5.7 \mathrm{~mm}$ in total length. An instantaneous fecundity (total number of eggs/female) was calculated from histological sections of 62 females collected at the Balanus and Kelvin Seamounts in May. Total egg numbers ranged from a minimum of 67 to a maximum of 3087 eggs.

The gonads of both sexes are associated with a nexus of blood vessels extending from the posterior surface of the 

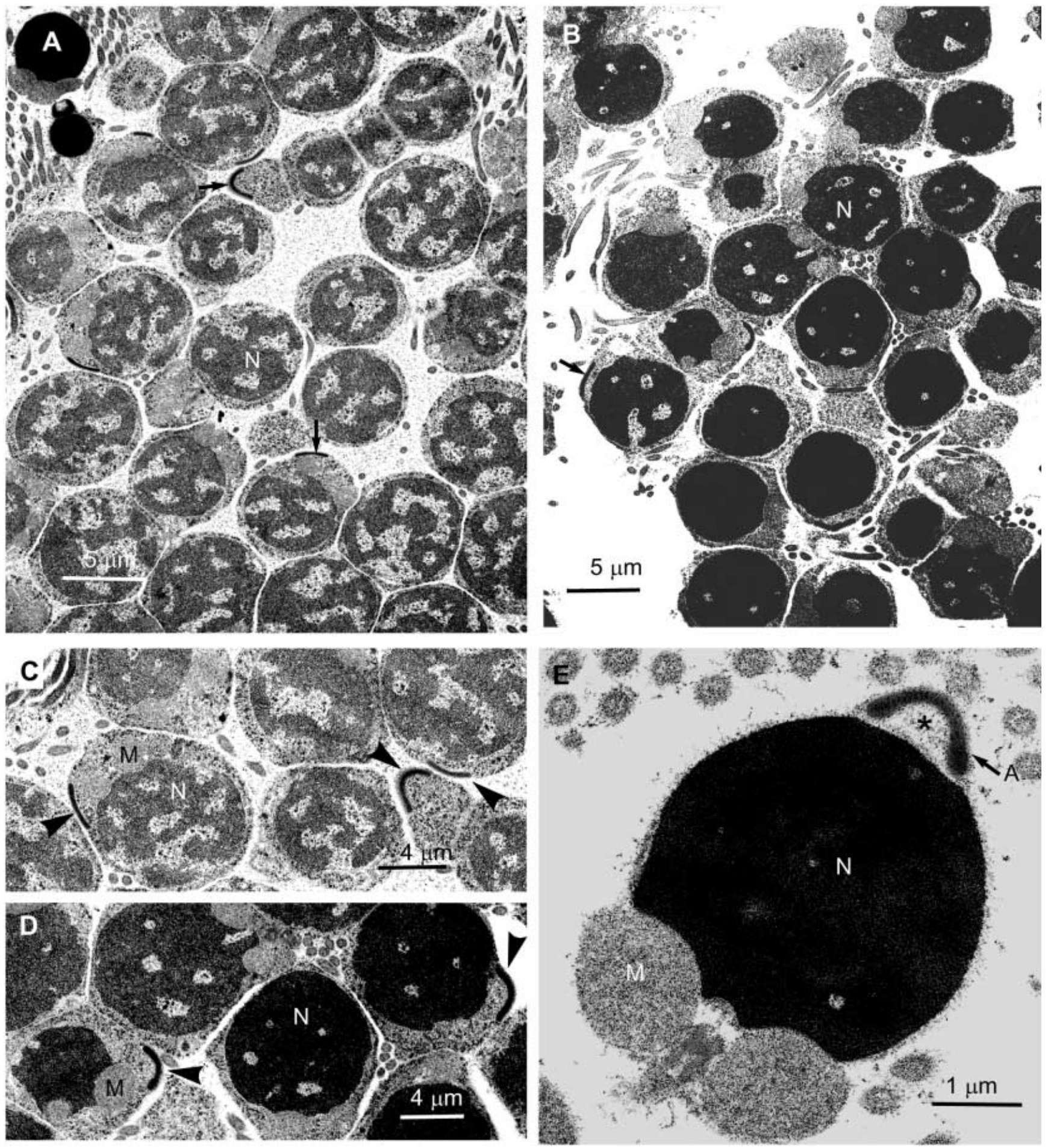

Figure 5. Electron micrographs of developing sperm. (A) Early spermatids with large nuclei (N) with uncondensed chromatin and peripheral acrosomal vesicles (arrows); (B) later spermatids with electron dense nuclei (N) and peripheral acrosomal vesicles (arrows); (C) early spermatids showing forming acrosomal vesicles (arrowheads). M, mitochondrion; N, nucleus; (D) later spermatids showing condensed chromatin in nucleus $(\mathrm{N})$, acrosomal vesicle (arrowheads), and mitochondria (M); (E) mature spermatozoon with spherical nucleus $(\mathrm{N})$, cap-like acrosome $(\mathrm{A})$ with flocculent subacrosomal space $(*)$, and mid-piece mitochondria $(\mathbf{M})$.

intersegmental septa. In the female, oogenesis is intraovarian in that oocytes are retained within the ovary through vitellogenesis while surrounded by a thin layer of follicle cells (Figure 1F). The females examined contained only mature eggs with no signs of any earlier oocyte stages (Figure 1C-E). Developing oocytes are attached to blood vessels that extend from the intersegmental septa (Figure
1C) and are released into the coelomic fluid when mature (Figure 1D). Intracoelomic oocytes measured from histological sections were $80-90 \mu \mathrm{m}$ in diameter and contained moderate quantities of yolk, prominent nuclei, and a single nucleolus (Figure 1E). Ultrastructural examination revealed a thin egg envelope with relatively few, short microvilli (Figure $1 \mathrm{~F}$ ). 
Table 1. Life history traits of the Polynoidae.

\begin{tabular}{|c|c|c|c|c|c|c|c|c|}
\hline Species & $\begin{array}{c}\text { Egg } \\
\text { diameter } \\
(\mu \mathrm{m})\end{array}$ & $\begin{array}{l}\text { Fertili- } \\
\text { zation } \\
\text { mode }\end{array}$ & $\begin{array}{l}\text { Larval } \\
\text { type }\end{array}$ & Oogenesis & Sperm & $\begin{array}{l}\text { Breeding } \\
\text { frequency }\end{array}$ & $\begin{array}{l}\text { Sexual } \\
\text { dimorphism }\end{array}$ & Reference \\
\hline Acholoe astericola & & broadcast & plankto & & & & & Bhaud \& Cazaux, 1987 \\
\hline $\begin{array}{l}\text { Acholoe squa- } \\
\quad \text { mosa }\end{array}$ & 100 & broadcast & plankto & & & & & Bhaud \& Cazaux, 1987 \\
\hline Antionella sarsi & $139-160$ & & plankto & & & seasonal & & $\begin{array}{l}\text { Rasmussen, 1973; } \\
\text { Curtis, } 1977\end{array}$ \\
\hline Arctonoe fragilis & 80 & broadcast & plankto & intraovarian & $\begin{array}{l}\text { ect- } \\
\text { aquasperm }\end{array}$ & & & Pernet, 2000 \\
\hline Arctonoe pulchra & 80 & broadcast & plankto & intraovarian & & & & Pernet, 2000 \\
\hline Arctonoe vittata & $80-83$ & broadcast & plankto & intraovarian & & seasonal & & $\begin{array}{c}\text { Britayev et al., 1986; } \\
\text { Britayev, 1991; } \\
\text { Pernet, } 2000\end{array}$ \\
\hline $\begin{array}{l}\text { Branchipolynoe } \\
\text { seepensis }\end{array}$ & $395-400$ & internal & $\begin{array}{l}\text { lecitho } \\
\text { or direct }\end{array}$ & intraovarian & elongate & $\begin{array}{l}\text { quasi- } \\
\text { continuous }\end{array}$ & yes & $\begin{array}{l}\text { Van Dover et al., 1999; } \\
\text { Jollivet et al., } 2000\end{array}$ \\
\hline Gattyana cirrosa & $90-120$ & & plankto & & & seasonal & & $\begin{array}{l}\text { Rasmussen, 1973; } \\
\text { Curtis, } 1977\end{array}$ \\
\hline $\begin{array}{l}\text { Gorgoniapolynoe } \\
\text { caeciliae }\end{array}$ & $80-90$ & broadcast? & plankto & intraovarian & $\begin{array}{l}\text { ect- } \\
\text { aquasperm }\end{array}$ & seasonal & no & Present study \\
\hline $\begin{array}{l}\text { Halosydna } \\
\quad \text { brevisetosa }\end{array}$ & $100-120$ & broadcast & plankto & & & seasonal & & $\begin{array}{l}\text { Blake, 1975; } \\
\text { Buzhinkakaya, } 1982\end{array}$ \\
\hline $\begin{array}{l}\text { Halosydna } \\
\text { gelatinosa }\end{array}$ & 100 & broadcast & plankto & & & & & Bhaud \& Cazaux, 1987 \\
\hline $\begin{array}{l}\text { Halosydna } \\
\text { johnsoni }\end{array}$ & & broadcast & plankto & & & & & Reish, 1980 \\
\hline $\begin{array}{l}\text { Harmothoe } \\
\text { derjugini }\end{array}$ & 150 & & & & & & & Britayev \& Ivanova, 1985 \\
\hline $\begin{array}{r}\text { Harmothose } \\
\text { extenuata }\end{array}$ & 95 & & plankto & & & & & Pettibone, 1963 \\
\hline $\begin{array}{l}\text { Harmothoe } \\
\text { glabra }\end{array}$ & & broadcast & plankto & & & & & Bhaud \& Cazaux, 1987 \\
\hline $\begin{array}{l}\text { Harmothoe } \\
\text { imbricata }\end{array}$ & $120-150$ & broadcast & plankto & & elongate & seasonal & yes & $\begin{array}{l}\text { Cazaux, 1968; Daly, 1972, } \\
\text { 1973, 1974; Daly et al., } \\
\text { 1972; Rasmussen, 1973; } \\
\text { Blake, 1975; Garwood, } \\
\text { 1981 }\end{array}$ \\
\hline Harmathoe impar & & & plankto & & & seasonal & & Rasmussen, 1973 \\
\hline $\begin{array}{l}\text { Harmothoe } \\
\quad \text { longisetis }\end{array}$ & & broadcast & plankto & & & & & $\begin{array}{l}\text { Bhaud \& Cazaux, 1987; } \\
\text { Wilson, } 1991\end{array}$ \\
\hline $\begin{array}{r}\text { Harmothoe } \\
\text { lunulata }\end{array}$ & $75-80$ & broadcast & plankto & & & & & Bhaud \& Cazaux, 1987 \\
\hline $\begin{array}{r}\text { Laetmodice } \\
\text { producta }\end{array}$ & 150 & & & & & & & Britayev \& Ivanova, 1985 \\
\hline $\begin{array}{l}\text { Lagisca } \\
\quad \text { extenuata }\end{array}$ & 95 & broadcast & plankto & & & & & $\begin{array}{l}\text { Cazaux, 1972; Bhaud \& } \\
\text { Cazaux, } 1987\end{array}$ \\
\hline Lepidonotus clava & 100 & broadcast & plankto & & & & & Bhaud \& Cazaux, 1987 \\
\hline $\begin{array}{l}\text { Lepidonotus } \\
\text { crinulatus }\end{array}$ & & & & & $\begin{array}{l}\text { ect- } \\
\text { aquasperm }\end{array}$ & & & Jamieson \& Rouse, 1989 \\
\hline Lepidonotus sp. & & broadcast? & & & $\begin{array}{l}\text { ect- } \\
\text { aquasperm }\end{array}$ & & & Rouse, 1988 \\
\hline $\begin{array}{l}\text { Lepidonotus } \\
\text { squamatus }\end{array}$ & $100-120$ & broadcast & plankto & & $\begin{array}{l}\text { ect- } \\
\text { aquasperm }\end{array}$ & seasonal & & $\begin{array}{r}\text { Franzén, 1956; Rasmussen, } \\
\text { 1973; Bhaud \& Cazaux, } \\
\text { 1987; Strathmann, } 1987\end{array}$ \\
\hline $\begin{array}{l}\text { Opisthochopodus } \\
\text { sp nov. }\end{array}$ & 420 & internal & $\begin{array}{l}\text { lecitho } \\
\text { or direct }\end{array}$ & intraovarian & elongate & $\begin{array}{l}\text { quasi- } \\
\text { continuous }\end{array}$ & yes & \\
\hline
\end{tabular}

The coelomic cavities of all males examined were filled with free-floating mature sperm with a far smaller number of earlier sperm stages associated with the genital blood vessels. The testes consist of small clusters of spermatogonia, spermatocytes, and early spermatids that extend from the posterior face of the intersegmental septa (Figure $1 \mathrm{G}-\mathrm{I}$ ). Early spermatids are shed from the testis into the coelomic fluid where they develop into mature sperm (Figures II \& 5A,B). Early spermatids are spherical cells dominated by large nuclei in which the chromatin is 
uncondensed and patchy in appearance (Figure 5A). The differentiating acrosomal vesicle and associated mitochondria are observed at high magnification (Figure 5G). Late spermatids have nuclei with condensed chromatin (Figure 5B). The mature spermatozoon (Figure 5E) is an ectaquasperm consisting of a spherical head (nucleus) of $4 \mu \mathrm{m}$, a small, semi-spherical, cap-like acrosome with a thickened posterior rim and no substructure, a flocculent subacrosomal space, a small mid-piece containing four spherical mitochondria, and a flagellum.

\section{DISCUSSION}

The reproductive biology of Gorgoniapolynoe caeciliae closely parallels that of many shallow water polynoids indicating no apparent evolutionary modifications resulting from its deep-sea habitat and/or commensal life style. While various external morphological modifications have been described among commensal polynoids (Pettibone, 1991), Martin \& Britayev (1998) note that their reproductive biology appears to differ little from their free-living relatives although little information has been available. Some elements of the reproductive biology and development of polynoids have been described for at least 24 species, including several symbiotic species (Wilson, 1991; Giangrande, 1997). A summary of reproductive features among known species of the Polynoidae (Table 1) shows a conservatism in their life history patterns with most species having seasonal breeding, intraovarian oogenesis, small eggs that develop planktotrophically, and simple, ect-aquasperm that develop as clonal cells while attached to the genital blood vessels. These collective reproductive features appear to be phylogenetically constrained. However, notable exceptions to this pattern have been described among two polynoids that occupy the same hydrothermal vent mussel beds (Bathymodiolus spp.). Branchipolynoe seepensis, a commensal living in the mantle cavity of the mussels and Opisthotrochopodus sp. nov., a free-living polynoid, both have sperm with elongate heads, quasi-continuous/asynchronous gametogenesis, internal fertilization, and large eggs that likely undergo non-planktotrophic development (Van Dover et al., 1999; Jollivet et al., 2000). It must be noted, however, that these two species are placed in separate subfamilies from Gorgoniapolynoe caeciliae (Branchipolynoinae and Branchinotogluminae, respectively) and are presently restricted to deep-sea reducing environments. It is interesting that these two species have nearly identical reproductive biologies despite the apparent differences in their respective life styles.

The results of our coelomic sampling suggests that Gorgoniapolynoe caeciliae is an annual, spring breeder like other polynoids although we were unable to take seasonal samples to confirm this. Our conclusion is based on the fact that all females sampled at Kelvin Seamount in two May samples contained only mature eggs while no sex products were detected in July samples from the same seamount suggesting that spawning had occurred. In contrast, Giangrande (1997) noted that the majority of deep-sea polychaetes show continuous breeding. Surprisingly, only one deep-sea polychaete, the non-vent spionid, Aurospio dibranchiata, is reported to have a seasonal reproductive pattern with the majority of species showing a likely continuous breeding pattern (Blake, 1993). Blake (1993) summarized studies of 15 polychaete species in 11 families from hydrothermal vent and non-vent habitats that reflected the latter pattern. Included in this list is the polynoid, Bathynoe cascadiensis, a continental shelf species. Another non-vent species, Cossura longocirrata, reproduces predominately during the summer but may be capable of year-round breeding (Blake, 1993). All of the polychaetes associated with hot vents reproduce throughout the year, including two alvinellids and one ampharetid (reviewed in Young, 2003). The methane seep hesionid, Hesiocaeca methanicola, undergoes synchronous gametogenesis but its breeding frequency could not be determined conclusively due to the lack of seasonal sampling (Eckelbarger et al., 2001).

If Gorgoniapolynoe caeciliae does undergo seasonal breeding, it would be of interest to know what, if any, environmental cues play a role, and if coordinated mating behaviour is involved. The breeding biology of the shallow water polynoid, Harmothoe imbricata has been extensively investigated and indicates that day length and temperature govern the rate of vitellogenesis resulting in the synchronization of germ cell development (Garwood, 1981). Since $G$. caeciliae occupies a deep-sea habitat, changing temperature and photoperiodic factors are unlikely to play a role. On the other hand, the spring phytoplankton bloom is a significant oceanographic feature of the North Atlantic Ocean (Harrison et al., 1993). At $40^{\circ} \mathrm{N} 47^{\circ} \mathrm{W}$ (north and east of our study sites), the largest phytoplankton pigment concentrations, as determined from satellite image data, occurred during the month of March during the years 1979-1986. About 38\% of the particulate organic carbon produced was exported through the base of the photic zone in late April-early May 1989, considerably later than the peak bloom period of previous years (Harrison et al., 1993), suggesting that considerable phytoplankton energy might be available to the benthos sometime in the late March to late April time period.

A relatively complex mating behaviour has been described in Harmothoe imbricata (Daly, 1972, 1973; Daly et al., 1972) and evidence suggests that internal fertilization occurs in the vent-associated polynoids, Branchipolynoe seepensis (Van Dover et al., 1999; Jollivet et al., 2000) and Opisthotropodus sp. nov. (Van Dover et al., 1999) requiring coordinated mating. In all of these species, sexual dimorphisms are apparent and the males produce filiform sperm with elongated heads (lengths $=28.0$ to $50 \mu \mathrm{m}$ ), indicating a modified form of fertilization. In contrast, externally-fertilizing polynoids such as Lepidonotus sp. (Rouse, 1988), Harmothoe impar (Franzén, 1956; Bentley \& Serries, 1992), H. extenuata and H. lunulata (Franzén, 1956) have ect-aquasperm with small rounded heads (lengths $=2.7$ to $3.6 \mu \mathrm{m}$ ) closely resembling those of Gorgoniapolynoe caeciliae. The presence of ect-aquasperm and the lack of sexual dimorphism in $G$. caeciliae lead us to believe that elaborate mating behaviour and internal fertilization are not likely to occur. In addition, we never observed sperm or sperm storage organs in any of the females we examined histologically.

Young (2003) points out in a recent review that annual or lifetime fecundities are very useful for ecologists but are nearly impossible to calculate for deep-sea polychaetes due to the paucity of life history information. As an alternative, 
instantaneous fecundity estimates are applied where possible. The present study is among a very few to provide estimates of instantaneous fecundity for any nonvent, deep-sea polychaete with the largest female G. caeciliae carrying over 3000 eggs. Blake (1993) reported approximately 160 eggs per gravid female in the sigalionid, Pholoe anoculata, and only two eggs for the orbinid, Microrbinia lineata. Britayev (1991) estimated up to 1,000,000 eggs in large females of the commensal polynoid Arctonoe vittata. Estimates for hydrothermal vent species range from $\sim 4000$ eggs in Paralvinella grasslei (Zal et al., 1995), 230,000 in the larger-bodied alvinellid Alvinella pompejana (Chevaldonné et al., 1998), and up to 700,000 mature eggs in the ovisac of the large siboglinid tubeworm, Riftia pachyptila (Young, 2003).

The specimens for this study were collected during two 'Mountains-in-the-Sea' cruises funded by the US NOAA's Ocean Exploration programme. We are extremely grateful to the pilots and crew of the submersible 'Alvin' and its support ship RV 'Atlantis' for their dedication and support during our 2003 cruise. We also want to thank the crew of the NOAA RV 'Ronald H. Brown' and express our appreciation to the support team and pilots of the Institute for Exploration's ROV 'Hercules' for their ingenuity and dedication to the success of our mission in 2004. Special thanks also to our fellow MIS co-Principal-Investigators, P. Auster, I. Babb, L. Mullineaux, J. Moore, and S. France for their help during and after the cruises, and to A. Simpson, S. Mills, and B. Halgren who helped at sea or in the laboratory with sorting worms and measuring corals. H. Fournier was supported during the summer of 2004 on a NSF REU summer internship (NSF 0139114).

\section{REFERENCES}

Bayer, F.M., 1964. The genus Corallium (Gorgonacea: Scleraxonia) in the western North Atlantic Ocean. Bulletin of Marine Science of the Gulf and Caribbean, 14, 465-478.

Bentley, M.G. \& Serries, K., 1992. Sperm ultrastructure in two species of the polychaete genus Harmothoe (Polynoidae). Helgoländer Meeresuntersuchungen, 46, 171-183.

Bhaud, M. \& Cazaux, C., 1987. Description and identification of polychaete larvae: their implications in current biological problems. Oceanis, 13, 596-753.

Blake, J.A., 1975. The larval development of Polychaeta from the northern California Coast. III. Eighteen species of Errantia. Ophelia, 14, 23-84.

Blake J.A., 1993. Life history analysis of five dominant infaunal polychaete species from the continental slope off North Carolina. Fournal of the Marine Biological Association of the United Kingdom, 7, 123-141.

Blake, J.A. \& Watling, L., 1994. Life history studies of deep-sea benthic infauna: Polychaeta, Aplacophora, and Cumacea from the continental slope off Massachusetts. In Reproduction, larval biology, and recruitment of the deep-sea benthos (ed. C.M. Young and K.J. Eckelbarger), pp. 244-260. New York: Columbia University Press.

Britayev, T.A., 1991. Life cycle of the symbiotic scaleworm Arctonoe vittata (Polychaeta: Polynoidae). Ophelia, Supplement, 5, 305-312.

Britayev, T.A. \& Ivanova, I.M., 1985. Comparative morphology of the reproductive system of polychaetes of the superfamily Aphroditacea. Issledovaniya Fauny Morei, 34, 10-15.
Britayev T.A., Medvedeva, V.L.A. \& Radashevsky, V.I., 1986. Reproduction and development of a symbiotic polychaete, Arctonoe vittata (Polynoidae), in the Vostok Bay of the Sea of Japan. Zoologichesky Zhurnal, 65, 713-725.

Buzhinkakaya, G.N., 1982. Seasonal changes in the abundance of prolific species of errant polychaetes (Polychaeta, Erantia) in Posyet Bay of the Sea of Japan. Issledovaniya Fauny Morei, 28, 74-87.

Cazaux, C., 1968. Étude morphologique du développement larvaire d'annélides polychètes (Bassin d'Arcachon). I. Aphroditidae, Chrysopetalidae. Archives de Zoologie Experimentale et Génerale, 109, 477-543.

Curtis, M.A., 1977. Life cycles and population dynamics of marine benthic polychaetes from the Kisko Bay area of West Greenland. Ophelia, 16, 9-58.

Daly, J.M., 1972. The maturation and breeding biology of Harmothoe imbricata (Polychaeta: Polynoidae). Marine Biology, 12, 53-66.

Daly, J.M., 1973. Some relationships between the process of pair formation and gamete maturation in Harmothoe imbricata (L) (Annelida: Polychaeta). Marine Behaviour and Physiology, 1, 277-284.

Daly, J.M., 1974. Gametogenesis in Harmothoe imbricata (Polychaeta: Polynoidae). Marine Biology, 25, 35-40.

Daly, J.M., Evans, S.M. \& Morely, J., 1972. Changes in behaviour associated with pair formation in the polychaete Harmothoe imbricata (L.). Marine Behaviour and Physiology, 1, 49-69.

Davenport, D., 1966. The experimental analysis of behavior in symbioses. In Symbiosis. I. Associations of microorganisms, plants and marine organisms (ed. S.M. Henry), pp. 381-429. New York: Academic Press.

Eckelbarger, K.J. \& Young, C.M., 1999. Ultrastructure of gametogenesis in a chemosynthetic mytilid bivalve (Bathymodiolus childressi) from a bathyal, methane seep environment (northern Gulf of Mexico). Marine Biology, 135, 635-646.

Eckelbarger, K.J. \& Young, C.M., 2002. Spermiogenesis and modified sperm morphology in the "seepworm" Methanoaricia dendrobranchiata (Polychaeta: Orbiniidae) from a methane seep environment in the Gulf of Mexico: implications for fertilization biology. Biological Bulletin. Marine Biological Laboratory, Woods Hole, 203, 134-143.

Eckelbarger, K.J., Young, C.M., Ramirez-Llodra, E., Brooke, S. \& Tyler, P., 2001. Gametogenesis, spawning behavior, and early development in the "iceworm" Hesiocaeca methanicola (Polychaeta: Hesionidae) from methane hydrates in the Gulf of Mexico. Marine Biology, 138, 761-775.

Eckelbarger, K.J. \& Watling, L., 1995. Role of phylogenetic constraints in determining reproductive patterns in deep-sea invertebrates. Invertebrate Biology, 114, 256-269.

Franzén, §̊., 1956. On spermiogenesis, morphology of the spermatozoon, and biology of fertilization among invertebrates. Zoologiska Bidrag fran Uppsala, 31, 355-482.

Garwood, P.R., 1981. Observations on the cytology of the developing female germ cell in the polychaete Harmothoe imbricata (L.). International Fournal of Invertebrate Reproduction, 3, 333-345.

Giangrande, A., 1997. Polychaete reproductive patterns, life histories: an overview. Oceanography and Marine Biology. Annual Review, 35, 323-386.

Harrison, W.G., Head, E.J.H., Horne, E.P.W., Irwin, B., Li, W.K.W., Longhurst, A.R., Paranjape, M.A. \& Platt, T., 1993. The western North Atlantic Bloom Experiment. Deep-Sea Research II, 40, 270-305.

Hodgson, A.N., Eckelbarger, K.J. \& Young, C.M., 1998. Sperm morphology and spermiogenesis in the methane seep mollusk Bathynerita naticoidea (Gastropoda: Neritacea) from the Louisiana slope. Invertebrate Biology, 117, 199-207.

Jamieson, B.G.M. \& Rouse, G.W., 1989. The spermatozoa of the Polychaeta (Annelida): an ultrastructural review. Biological Reviews, 64, 93-157. 
Jollivet, D., Empis, A., Baker, M.C., Hourdez, S., Comtet, T., Jouin-Toulmond, C., Desbruyeres, D. \& Tyler, P.A., 2000. Reproductive biology, sexual dimorphism, and population structure of the deep-sea hydrothermal vent scale-worm, Branchipolynoe seepensis (Polychaeta: Polynoidae). Journal of the Marine Biological Association of the United Kingdom, 80, $55-68$.

Levenstein, R.Y., 1984. On the ways of formation of the deep-sea polychaete fauna of the family Polynoidae. In Proceedings of the first international polychaete conference (ed. P.A. Hutchings), pp. 7285. Sydney: The Linnean Society of New South Wales.

Martin, D. \& Britayev, T.A., 1998. Symbiotic polychaetes: review of known species. Oceanography and Marine Biology. Annual Reviere, 36, 217-340.

McHugh, D. \& Tunnicliffe, V., 1994. Ecology and reproductive biology of the hydrothermal vent polychaete Amphisamytha galapagensis (Ampharetidae). Marine Ecology Progress Series, 106, 111-120.

Pernet, B., 2000. Reproduction and development of three symbiotic scaleworms (Polychaeta: Polynoidae). Invertebrate Biology, 119, 45-57.

Pettibone, M.H., 1963. Marine polychaete worms of the New England region. I. Aphroditidae through Trochochaetidae. Bulletin. United States Natural History Museum, 227, 1-356.

Pettibone, M.H., 1984. A new scale-worm commensal with deepsea mussels on the Galapagos hydrothermal vent (Polychaeta: Polynoidae). Proceedings of the Biological Society of Washington, 97, 226-239.

Pettibone, M.H., 1991. Polynoids commensal with gorgonian and stylasterid corals, with a new genus, new combinations, and new species (Polychaeta: Polynoidae: Polynoinae). Proceedings of the Biological Society of Washington, 104, 688-713.
Rasmussen, E., 1973. Systematics and ecology of the Isefjord marine fauna (Denmark). Ophelia, 11, 1-495.

Reish, D.J., 1980. The effect of different pollutants on ecologically important polychaete worms. EPA Research Report, EPA 600/380-053, 1-138.

Rouse, G.W., 1988. An ultrastructural study of the spermatozoa of Eulalia sp. (Phyllodocidae), Lepidonotus sp. (Polynoidae), Lumbrineris sp. (Lumbrineridae) and Owenia fusiformis (Oweniidae). Helgoländer Meeresuntersuchungen, 42, 67-78.

Strathmann, M.F., ed., 1987. Phylum Annelida, Class Polychaeta. In Reproduction and development of marine invertebrates of the northern Pacific coast, pp. 138-195. Seattle: University of Washington Press.

Tunnicliffe, V., MacArthur, A.G. \& McHugh, D., 1998. A biogeographical perspective of the deep-sea hydrothermal vent fauna. Advances in Marine Biology, 34, 355-442.

Tyler, P.A. \& Young, C.M., 1999. Reproduction and dispersal at vents and cold seeps. Fournal of the Marine Biological Association of the United Kingdom, 79, 193-208.

Van Dover, G.L., Trask, J., Gross, J. \& Knowlton, A., 1999. Reproductive biology of free-living and commensal polynoid polychaetes at the Lucky Strike hydrothermal vent field (Mid-Atlantic Ridge). Marine Ecology Progress Series, 181, 201-214.

Wilson, W.H., 1991. Sexual reproductive modes in polychaetes: classification and diversity. Bulletin of Marine Science, 48, 500-516.

Young, G.M., 2003. Reproduction, development and life-history traits. In Ecosystems of the world. Vol. 28. Ecosystems of the deep oceans (ed. P.A. Tyler), pp. 381-426. Amsterdam: Elsevier.

Submitted 29 November 2004. Accepted 27 June 2005. 